\title{
The Infusion Of Propaganda In The Music Education In China
}

\author{
Louie Giray \\ College of Teacher Education \\ Polytechnic University of the Philippines \\ email: lggiray@pup.edu.ph
}

Received: 13 August 2021; Revised: 02 October 2021; Accepted: 14 December 2021

DOI: http://dx.doi.org/10.37905/aksara.8.1.1-6.2022

\begin{abstract}
Under the administration of the Communist China, the distinction between education and propaganda cannot be made. Various research and literatures reveal that many resources used by Chinese educational institutions, such as books and songs, are modified in order to inject views that favor People's Republic of China and ideologies from the Communist Party. This perspective paper explores the infusion of propaganda undertaken in the education in the Communist China. It also provides a discussion on both the advantages and disadvantages of such conduct. Particularly, it elaborates on the concepts of self-preserving maneuver for social stability and country's survival; emphasis on the welfare of the state; the domino effect in altering musical pieces; corrupted education and altered truth; manifestation of the superiority and authoritarianism of the ruling party; and the ideological remolding to establish loyalty and nationalism. It is recommended that in order for China to be faithful to its slogan, diversity in unity, respecting differences on musical works of ethnicities and not intervening on them would be a decent starting point.
\end{abstract}

Keywords: Communist China, music education, propaganda, Chinese education

\section{INTRODUCTION}

China is the world's most populous country, with approximately 1 billion inhabitants (Yixing \& Ma, 2003); as a result, it also has the largest number of students. In 2016, China has approximately 30 million students and 15 million teachers (OECD, 2016). Meanwhile, China can be described as a multiracial nation. It has 56 ethnicities, more than 80 spoken dialects, and about 30 written languages (Yuan, 2017). Chinese Communist Party claims to stand for diversity in unity of China (Yongjing, 2009). This is made possible by the CCP's Propaganda Department, the People's Republic of China's (PRC) only ruling party. The department oversees ideological work, intelligence distribution, and media censorship (Brady, 2009).

Propaganda is the dissemination of information in favor of a cause-regardless if the information is real or incorrect, or whether the cause is just or not (Bernays, 2008). It is widespread in PRC and is instituted by the ruling party. Since the Communists gained power in China, propaganda, during the Mao period, has become noted for its consistent use of mass movements to legitimize the regime and leaders' policies (Welsch, 2013). The education sector cannot escape propaganda. Political indoctrination has long been a necessary part of Chinese education at all levels (Leung, 2004). Indeed, the central Chinese government has regarded school education as a means to create a cohesive, nationalist, and party-loving national culture (Kipnis, 2012). One strategy for making this a reality is to penetrate music education.

In terms of music education in China, Zhang (2017) revealed in his study that (1) only 24 out of 56 ethnic groups are represented in the K1-9 national music textbooks; (2) 75 percent of ethnic pieces were adapted or composed rather than becoming traditional tunes; and (3) 85 percent of ethnic works demonstrate cultural and political 
ideologies such as tribute for the Communist party and the establishment. Though musical works should represent the cultures and subcultures from which they are derived, and musical values should be interpreted in terms of human circumstances and human experience (Ho \& Law, 2004), the situation in the PRC is different.

\section{METHOD}

The data from this manuscript were acquired from secondary data sources like books and journal articles from credible and peer-reviewed sources. The researcher used critical reflection as a research method to make sense of the data obtained. Critical reflection means regularly identifying and exploring thoughts and feelings in relation to a topic (Fook, 2011). It requires a complex understanding which the process enables (Kuhn, 2008). Afterward, thematic analysis was utilized.

\section{RESULTS AND DISCUSSION}

The results are thematically organized. The infusion of propaganda in music education in China has both positive and negative repercussions. Here are the themes: (1) self-preserving maneuver for social stability and country's survival; (2) emphasis on the welfare of the state; (3) the domino effect in altering musical pieces; (4) corrupted education and altered truth; (5) manifestation of the superiority and authoritarianism of the ruling party; and (6) the ideological remolding to establish loyalty and nationalism.

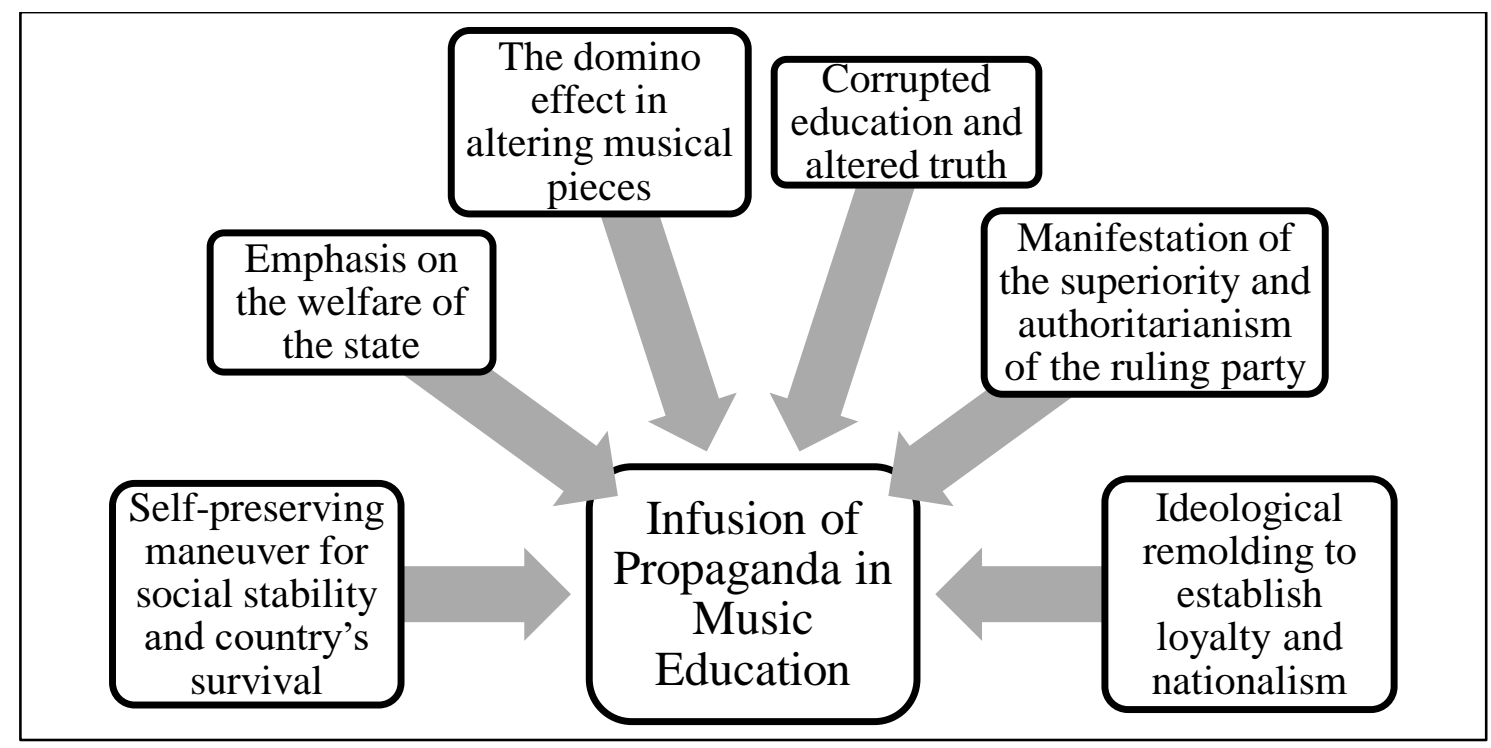

Figure 1. Themes on the Infusion of Propaganda in Music Education

\section{Self-preserving maneuver for social stability and country's survival}

The Chinese government employs music and music education as a powerful nation-building machine to deepen memory politics; in particular, it instills stateprescribed ideals in its people (Ho and Law, 2004). Education is an overt CCP party device intended to instill and preserve ideals, as well as a policy tool used to facilitate the state's modernization (Saywell, 1980). 
In order to establish control over the country, PRC is making its self-preserving maneuver-that is, through infiltrating the music education. This tactic of altering the lyrics of traditional ethnic music, through the injection of nationalistic lines and praises to the Communist party, unifies the country. It makes people get to learn implicitly and explicitly upright intentions and actions of PRC and CCP. This deliberate action ensures social stability and survival of the country. Therefore, this can be of help not to lessen disorder among people. Also, this aids the PRC to continue and exist.

\section{Emphasis on the welfare of the state}

According to Mohist consequentialism, which assesses the moral value of an activity depending on how much it adds to a state's wellbeing (Van Norden, 2007), the act of modifying the lyrics of ethnic music is justifiable because the purpose is decentto encourage nationalism. When cost-benefit analysis is used, more of the effects provide positive outcomes such as national welfare, cultural friendship, and social order.

Therefore, in this logic, it is morally upright since no harm seemingly is put into place. This is, likewise, desirable because it develops loyal and nationalistic citizens, which are the country's most valuable assets. Citizens are reinforced to think and care for their nation. Hence, this promotes the welfare of the homeland.

\section{The domino effect in altering musical pieces}

Vivid heritage of music is indeed part of the cultural landscape of an ethnicity. This is surprising that the government blatantly distorts the reality, which in this case, are the musical pieces as depicted in national textbooks. Music should mirror the culture and history of the land. However, in the China's case, it is not.

The authorities, who represent Communist ideologies, are responsible for the textbooks (Zhang, 2017) and find that changing lyrics will be of help to strengthen nationalism. If anything in the ethnic music is altered, its accompanied culture, traditions, and history, likewise will be affected. Lugubriously, the realistic depictions of the traditional ethnic music will be sacrificed, therefore.

\section{Corrupted education and altered truth}

Schools should promote truth and educate using truth (Cherryholmes, 1980). And a little bit of alteration is not truth anymore. Therefore, the change in the musical pieces, though miniscule, indeed is not truthful. It is done in a bad faith. They present it as truth, but it really is not. The schools have become as agents of deception so that young minds will see the country as a delightful place, with the emphasis on the unity among diverse ethnic groups, and will reinforce nationalism.

No matter how desirable the objectives are, the students are still receiving education, which is not founded on truth. They get education based on altered truth which undeniably is a lie. The learning on musical textbooks is presented as education. This music education, as mandated by the authorities, is not act of good faith and very perverted. They present it as education, but with forgery and falsity of the ethnic musical pieces. This can be considered as education with deception on the side-a corrupted education. 


\section{Manifestation of the superiority and authoritarianism of the ruling party}

Through the perspective of Instrumental Marxism, which notes that policymakers share a similar class history and that their decisions will represent their class interests (Pashukanis, 2017), one can see that the CCP, as the country's prevailing force, wields significant social and political influence. The party's interest is to instill a sense of nationalism in the people, and so the party uses its influence to accomplish the alteration of lyrics in textbook.

This is exemplified by the government's presence in music education, especially the use of patriotic and pro-communist elements in lyrics. Since the CCP is the governing party, this is a sign of its hegemony and authoritarianism. Songs, as a historically recognized type of information distribution channel, have been successful throughout Chinese history in conveying messages intended by the government (Saywell, 1980).

\section{Ideological remolding to establish loyalty and nationalism}

Using the principle of cultural hegemony, which argues that the dominant elite will control a society's belief structure such that their perspective becomes the world view (Huang, 2015), the indoctrination occurring in music education is a weapon of the CCP to manipulate the psyche of the students, who would most likely become obedient adult people. The CPP is actively engineering music education in compliance with their stateprescribed values through the Ministry of Education in order to massively condition the people to be faithful to the country.

However, such virtue is not rooted from genuine patriotism, because it is the fruition of the heedful and deliberate propagandistic activities of the government. Young people may be passionate about the country's welfare, but it is due to blinded nationalism; the foundation is not grounded on the solid love for the country. Schools are transmuted as agents for ideological remolding, not of critical and creative thinking, and appreciation for its real heritage.

\section{CONCLUSION}

This manuscript offered the presentation of both the positive and negative repercussions of the infusion of propaganda in music education in China. It is a provocative and charged topic. However, it should be talked about so that people, most especially the people in education sector, will be aware on how authorities can affect curriculum or school resources. In China's case, it is a deliberate alteration to put forward ideologies of CCP and for the benefit of the PRC. While it may offer desirable consequences such as students would perceive that their country is united and such reinforces nationalism among students, the alteration of lyrics on musical pieces in textbooks can be debilitating as well because their education is not founded on truth.

The authorities in China may have strived to aid their country's welfare. But, this is not a way to encourage harmony that they envision - it is artificial which can crack at any moment. Music education is beautiful and is appreciated by many individuals since through this that people can be acquainted with their culture and heritage. Nonetheless, if it altered, the passing our values will be affected such as authenticity is discredited. Music education can serve as a means to intellectually and emotionally stimulate students, but it would not be genuine if authorities continue to intervene on injecting ideologies and changing lyrics in music textbooks. In order for China to be faithful to its slogan, diversity 
in unity, respecting differences on musical works of ethnicities and not intervening on them would be a decent starting point.

\section{REFERENCES}

Bernays, E. L. (2008). Propaganda. Melusina.

Brady, A. M. (2009). Marketing dictatorship: Propaganda and thought work in contemporary China. Rowman \& Littlefield Publishers.

Brady, A. M. (2012). Ethnicity and the state in contemporary China. Journal of Current Chinese Affairs, 41(4), 3-9.

Cherryholmes, C. H. (1980). Social knowledge and citizenship education: Two views of truth and criticism. Curriculum Inquiry, 10(2), 115-141.

Fook, J. (2011). Developing critical reflection as a research method. In Creative spaces for qualitative researching (pp. 55-64). SensePublishers.

Ho, W. C., \& Law, W. W. (2004). Values, music and education in China. Music Education Research, 6(2), 149-167.

Huang, H. Y. (2015). Gramsci and Cultural Hegemony in Post-Mao China. Literature Compass, 12(8), 404-413.

Kipnis, A. B. (2012). Constructing commonality: Standardization and modernization in Chinese nation-building. The Journal of Asian Studies, 731-755.

Kuhn, L. (2008). Complexity and educational research: A critical reflection. Educational Philosophy and Theory, 40(1), 177-189.

Leung, Y. W. (2004). Nationalistic education and indoctrination. Citizenship, Social and Economics Education, 6(2), 116-130.

Organisation for Economic Co-operation and Development. (2016). Education in China: A snapshot. OECD Publishing.

Pashukanis, E. (2017). The general theory of law and Marxism. Routledge.

Saywell, W. G. (1980). Education in China Since Mao. Canadian Journal of Higher Education, 10(1), 1-27.

Van Norden, B. (2007). Virtue ethics and consequentialism in early Chinese philosophy. Cambridge University Press.

Welch, D. (Ed.). (2013). Propaganda, power and persuasion: From World War I to wikileaks. Bloomsbury Publishing.

Yixing, Z., \& Ma, L. J. (2003). China's urbanization levels: Reconstructing a baseline from the fifth population census. The China Quarterly, 176-196.

Yongjing, H. (2009). A Study on the System Structure of the Chinese Nation: Systematic Analysis on the Pattern of Diversity in Unity of the Chinese Nation [J]. NW Journal of Ethnology, 3.

Yuan, H. (2017). Multicultural teacher education in China: Preparing culturally responsive teachers in a multiethnic and multicultural country. US-China Education Review, 7(2), 85-97.

Zhang, W. (2017). Multicultural ethnic music education in Communist China. International Journal of Multicultural Education, 19(3), 65-84. 
AKSARA: Jurnal Ilmu Pendidikan Nonformal

P-ISSN 2407-8018 E-ISSN 2721-7310 DOI prefix 10.37905

Volume 08, (1), January 2022

http://ejurnal.pps.ung.ac.id/index.php/Aksara 